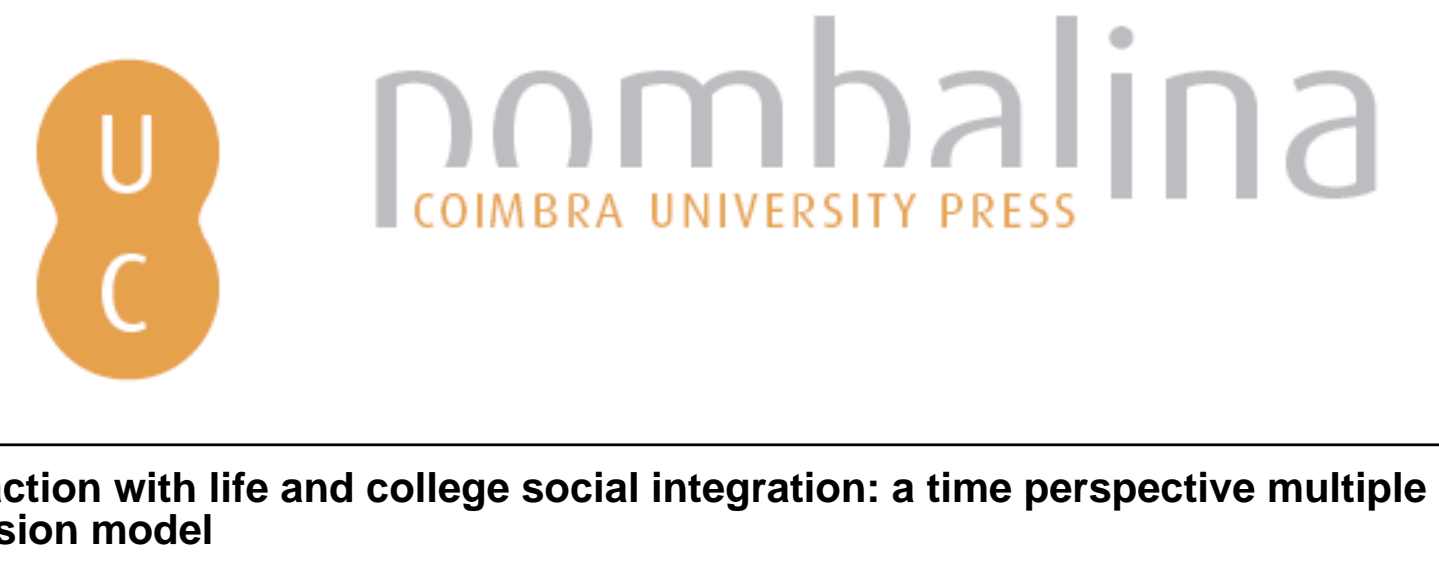

\title{
Satisfaction with life and college social integration: a time perspective multiple regression model
}
Autor(es):
Ortuño, Victor E. C.; Gomes, Catarina V. M.; Vásquez, Alejandro; Belo, Pedro; Imaginário, Susana; Paixão, Maria Paula; Janeiro, Isabel Nunes

Publicado por: Imprensa da Universidade de Coimbra

URL persistente:

URI:http://hdl.handle.net/10316.2/38614

DOI:

DOI:http://dx.doi.org/10.14195/978-989-26-0775-7_10

Accessed : $\quad$ 26-Apr-2023 09:50:34

A navegação consulta e descarregamento dos títulos inseridos nas Bibliotecas Digitais UC Digitalis, UC Pombalina e UC Impactum, pressupõem a aceitação plena e sem reservas dos Termos e Condições de Uso destas Bibliotecas Digitais, disponíveis em https://digitalis.uc.pt/pt-pt/termos.

Conforme exposto nos referidos Termos e Condições de Uso, o descarregamento de títulos de acesso restrito requer uma licença válida de autorização devendo o utilizador aceder ao(s) documento(s) a partir de um endereço de IP da instituição detentora da supramencionada licença.

Ao utilizador é apenas permitido o descarregamento para uso pessoal, pelo que o emprego do(s) título(s) descarregado(s) para outro fim, designadamente comercial, carece de autorização do respetivo autor ou editor da obra.

Na medida em que todas as obras da UC Digitalis se encontram protegidas pelo Código do Direito de Autor e Direitos Conexos e demais legislação aplicável, toda a cópia, parcial ou total, deste documento, nos casos em que é legalmente admitida, deverá conter ou fazer-se acompanhar por este aviso.

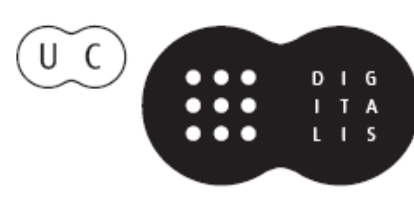




\section{INTERNATIONAL \\ STUDIES IN TIME \\ PERSPECTIVE}

MARIA PAULA PAIXÃO

JOSÉ TOMÁS DA SILVA

(COORD.)

VICTOR ORTUÑO

PEDRO CORDEIRO

(EDITORS)

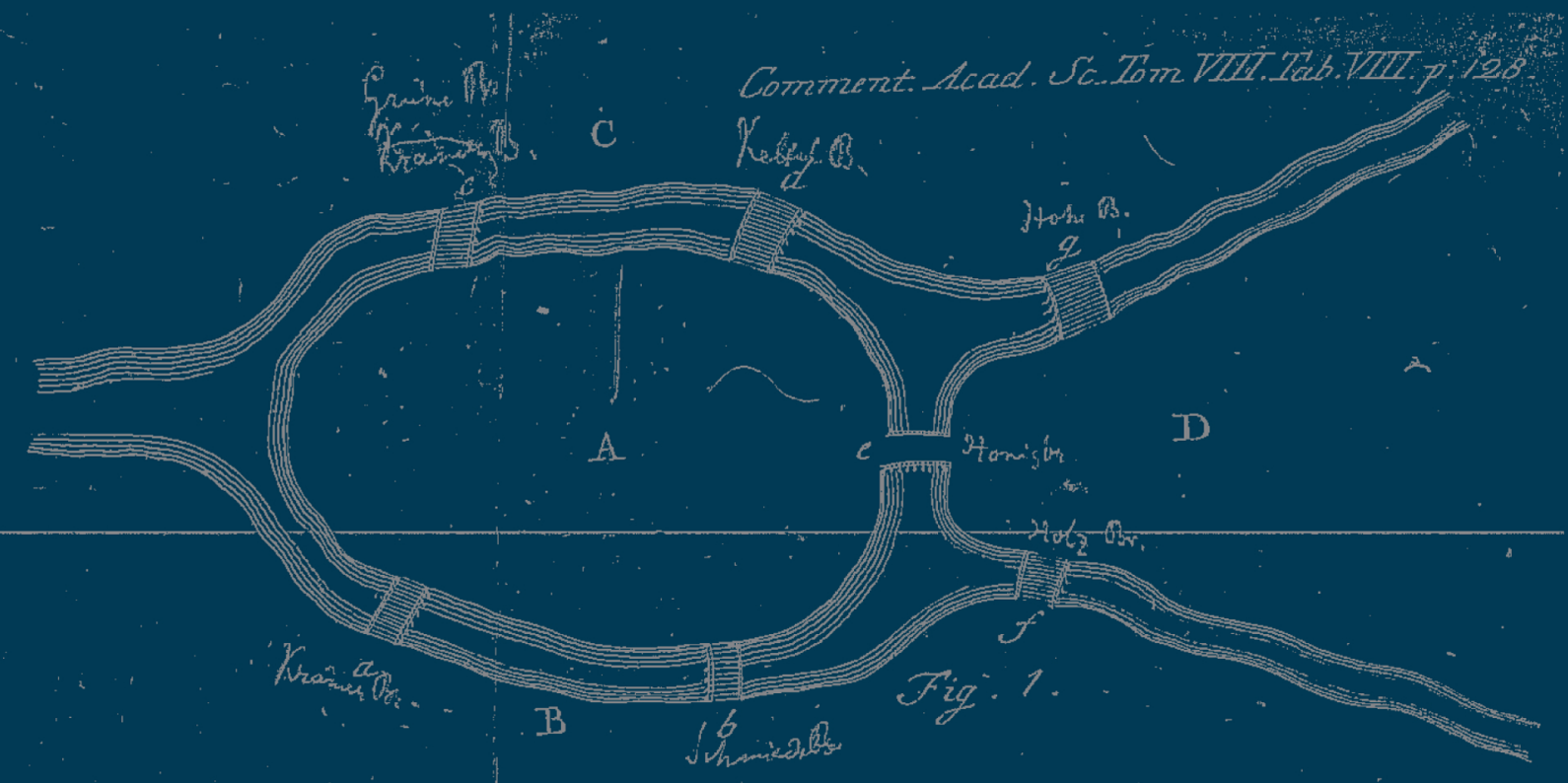

IMPRENSA DA

UNIVERSIDADE

DE COIMBRA

COIMBRA

UNIVERSITY

PRESS 
Chapter 10

Satisfaction with Life and College Social Integration: A Time PersPective Multiple Regression Model

\author{
Victor E. C. Ortuño \\ Faculty of Psychology and Educational Sciences, University of Coimbra, Portugal \\ victortuno@gmail.com
}

Catarina V. M. Gomes

Independent Practice, Porto, Portugal

\begin{abstract}
Alejandro Vásquez
Faculty of Psychology and Educational Sciences, University of Porto, Portugal

Faculty of Psychology, University of the Republic, Uruguay
\end{abstract}

\title{
Pedro Belo
}

Institute for Cognitive Psychology, Vocational \& Social Development,

University of Coimbra, Portugal

\section{Susana Imaginário}

Faculty of Human \& Social Sciences, University of Algarve, Portugal

\section{Maria Paula Paixão}

Faculty of Psychology and Educational Sciences, University of Coimbra, Portugal

\section{Isabel Nunes Janeiro}

Faculty of Psychology, University of Lisbon, Portugal

\begin{abstract}
Aвstract: Time Perspective - TP has a determinant influence on human behavior and cognitions. Hence, it's also a powerful predictor of several functional and dysfunctional behaviors (Zimbardo \& Boyd, 1999). Still, depending on the nature of the studied construct, different facets of TP should be considered. The objective of this study is to clarify the predictor power of TP in 4 constructs related to well-being. The sample is composed of 143 Portuguese College students, with ages between 17 and 54 years old. Through a series of Multiple Regression Analyses (Stepwise Method) TP appears as a moderate and significant predictor of: Satisfaction with Life (Adj. $R^{2}=.165, p<.001$ ); Interpersonal Relations (Adj. $R^{2}=.067, p<.01$ ); Psychological Well-Being (Adj. $R^{2}=.207, p<.001$ ) and Emotional Balance (Adj. $R^{2}=.115, p<.001$ ). These results highlight the role that TP has in the prediction of an adaptive psychological functioning.
\end{abstract}

Keywords: time perspective, motivation, well-being, ZTPI, multiple regression. 


\section{INTRODUCTION}

The study of subjective temporality has raised strong debates during the last 50 years. Several instruments and theoretical viewpoints were developed to gain better understanding about it. One of the most influential authors is probably Kurt Lewin, who defines subjective temporality or Time Perspective (TP) as "the totality of the individual's view of his psychological future and psychological past existing at a given time" (1951, p. 75). Thus, Lewin puts the emphasis on the study of present time, but without neglecting the influence that the various mental constructs of the individuals about the past and the future may have on affect, behavior and cognition. Therefore, all human activity takes place embedded in a context, which is composed by geo-socio-political features, but also by the temporal dimension which gives order to the same activities and processes, through its location along the temporal continuum (Lewin, 1951).

At present, one of the most widely used theoretical references for the research of time is the one proposed by Zimbardo and Boyd (1999). Continuing the thought of Lewin, these authors argue that Time Perspective is an unconscious process that assists individuals in encoding, storing and retrieving information related to personal and social objects that fill their life; this process makes it possible to bring order, meaning and coherence to these same objects through various time categories, which also allow a reinterpretation of all this information.

It was suggested that TP, as it is defined in terms of Lewin and operationalized by Zimbardo, is related to well-being. The Past-Negative sub-scale has been associated with depression, anxiety and lower scores of self-esteem. On the contrary, people that score high in Past Positive show more self-esteem, happiness and enjoy more social support. Individuals with higher present orientation are more prone to engage in health-related risk behaviors, and less in preventive behaviors (Boyd \& Zimbardo, 2005). In addition, subjects with a balanced time perspective were found to have more subjective well-being and more mindfulness (Drake et al., 2008).

The objective of this study is to identify the predictor power of TP in 4 constructs related to well-being and social integration into university among a sample of undergraduate students.

\section{Method}

\section{Participants}

The sample was composed of 143 participants with ages between 17 and 54 years old $(\mathrm{M}=19.63$, S.D. $=4.78) .125(89.3 \%)$ were females and $15(10.7 \%)$ males. Participants were recruited from the Faculties of Psychology and Educational Sciences of the University of Coimbra $(n=120)$ and the University of Porto $(n=23) .96(67.6 \%)$ attend the Integrated Master in Psychology, 44 (31\%) the Master in Educational Sciences and 2 (1.4\%) the Anthropology Undergraduate Degree. 138 (97.2\%) students were first year undergraduates. 


\section{Instruments}

All the data was collected using 6 instruments: a Socio-Demographic Questionnaire, the Portuguese adaptation of the Zimbardo Time Perspective Inventory - ZTPI (Zimbardo \& Boyd, 1999; Ortuño \& Gamboa, 2009), the Negative Future Scale from Inventário de Perspectiva Temporal - IPT (Janeiro, 2006), the Portuguese Transcendental-Future Time Perspective Scale - TFTPS (Boyd \& Zimbardo, 1997; Ortuño, Paixão \& Janeiro, 2013), the Satisfaction with Life Scale - SWLS (Diener, Emmons, Larsen \& Griffin, 1985; Neto, 2003) and the Scale of Social Integration in Higher Education - EISES (Diniz \& Almeida, 2005).

Socio-Demographic Questionnaire: Drawn up by the authors in order to characterize the sample (age, sex, course, course year, etc.).

Zimbardo Time Perspective Inventory - ZTPI (Zimbardo \& Boyd, 1999; Ortuño \& Gamboa, 2009): it is composed of 56 items (5-point Likert scale) which represents 5 temporal dimensions: 1) Past Positive, related to pleasant and warm attitudes towards the past (explained variance $=6.02 \%, \alpha=.68,9$ items), 2) Past Negative, represents an aversive and distressful attitude towards the past (variance explained $=7.85 \%, \alpha=.80,10$ items), 3 ) Present Hedonist, represents a tendency to seek immediate pleasure, through exciting and risky experiences (explained variance $=8.37 \%, \alpha=.79,15$ items), 4) Present Fatalist, shows a totally defeatist attitude towards life (explained variance $=6.42 \%, \alpha=.66,9$ items) and 5) Future, indicates a strong tendency to create and pursue long term objectives (variance explained $=6.57 \%, \alpha=.74,13$ items). These 5 temporal dimensions explain $35.25 \%$ of the total variance. This factor structure is very similar to that presented by Zimbardo and Boyd (1999) in the original ZTPI, and also in several international adaptations (Ortuño, Paixão \& Janeiro, 2011). Concerning the test/re-test validity, the Portuguese ZTPI shows values between .66 and .86 (Ortuño \& Gamboa, 2008).

Inventário de Perspectiva Temporal - IPT (Janeiro, 2012): it is formed by 32 items (7-point Likert-type scale), grouped in 4 temporal dimensions: 1) Past Orientation, 2) Present Orientation, 3) Future Orientation and 4) Negative Future. In this study we used only four items related to the negative future dimension (variance explained $=8 \%, \alpha=.70$, 4 items) which is related to an unpredictable and threatening vision of events yet to come.

Transcendental-Future Time Perspective Scale - TFTPS (Boyd \& Zimbardo, 1997; Ortuño, Paixão \& Janeiro, 2013): This is a one-dimension scale, formed by 10 items (5-point Likert scale). It evaluates the individual's beliefs and attitudes about the future after the death of the physical body. The original TFTPS explains $10 \%$ of the total variance, with a internal consistency of .87 and a test/re-test stability of .86 .

Satisfaction with Life Scale - SWLS (Diener et al., 1985; Neto, 2003): composed by 5 items (7-point Likert scale) in one dimension. It has an internal consistency of .78 and explains $53.3 \%$ of the variance. This scale evaluates the individual's life satisfaction as a cognitive-judgmental process.

Scale of Social Integration in Higher Education - EISES (Diniz \& Almeida, 2005): This scale was specially developed for Portuguese students and is composed of 14 items, evaluated in a 5-point Likert scale, divided into three dimensions: interpersonal relationship (Cronbach's alpha $=.68)$, personal well-being (.64) and emotional balance (.82). 


\section{Procedures \& Statistical Analyses}

All the data was collected in classrooms. The responses were standardized and any $\mathrm{Z}$ value higher than 2.5 or lower than -2.5 was considered an outlier. Several Multiple Regression Models were performed (Stepwise method) using 7 dimensions of TP as predictor variables of each model and 4 variables related with psychological well-being and social integration as criterion variables.

All the collected data was introduced into the statistical program Statistical Package for the Social Sciences - SPPS 16.0 (Windows version).

\section{RESULTS}

Four significant models were found for the 4 criterion variables (Table 1). Regarding Satisfaction with Life, the model composed of the Past Negative and Future Negative dimensions, predicts $17 \%(p<.001)$ of the results. As observed through the Beta Standardized Coefficient $(\beta)$, both temporal dimensions present a negative relation to the criterion variable.

Table 1 - SWLS \& EISES - Time Perspective Multiple Regression Models

\begin{tabular}{|c|c|c|c|c|c|c|c|c|c|c|c|}
\hline & $R^{2} a d j$ & $\Delta \mathrm{R}^{2}$ & $D F$ & $F$ & $p$ (Model) & $\beta$ & $t$ & $p$ & Tolerance & VIF & $\begin{array}{l}\text { Cond. } \\
\text { Index }\end{array}$ \\
\hline Satisfaction with Life (SWLS) & .165 & & 2,114 & 12.445 & .000 & & & & & & \\
\hline Past Negative & & .144 & & & & -.308 & -3.391 & .001 & .875 & 1.14 & 1.19 \\
\hline Future Negative & & .036 & & & & -.202 & -2.223 & .028 & .875 & 1.14 & 1.47 \\
\hline Interpersonal Relations (EISES) & .067 & & 1,114 & 9.198 & .003 & & & & & & \\
\hline Past Negative & & .075 & & & & -.273 & -3.033 & .003 & & & \\
\hline Psychological Well-Being (EISES) & .207 & & 3,113 & 11.072 & .000 & & & & & & \\
\hline Past Negative & & .136 & & & & -.228 & -2.498 & .014 & .817 & 1.22 & 1.33 \\
\hline Present Fatalist & & .062 & & & & -.201 & -2.169 & .032 & .795 & 1.26 & 1.63 \\
\hline Future Negative & & .029 & & & & -.194 & -2.051 & .043 & .761 & 1.31 & 1.75 \\
\hline Emotional Balance (EISES) & .115 & & 1,116 & 16.219 & .000 & & & & & & \\
\hline Future Negative & & .123 & & & & -.350 & -4.027 & .000 & & & \\
\hline
\end{tabular}

Past Negative is the only temporal variable in the Interpersonal Relations model and predicts $7 \%$ of the results $(p<.01)$. In this case, the predicting variable is also negatively related to the criterion variable.

The predictive model for Psychological Well-being is constituted by 3 temporal dimensions: Past Negative, Present Fatalist and Future Negative. All these three predictor variables are negatively related to the criterion variable. The model predicts $21 \%$ of the results $(p<.001)$.

Regarding Emotional Balance, the model is composed by Future Negative, which presents a negative relation to Emotional Balance, and predicts $12 \%$ of the results $(p<.001)$. 
No multicolinearity problems were found, since in all cases the Condition Index is below 15 and the Variance Inflation Factor (VIF) is below 10. In the Interpersonal Relations and Emotional Balance models these values are not shown since they are Simple Regression Models.

\section{Discussion}

A few core ideas emerged from the results of this study: (a) the individual's temporal profile must be analyzed according to the nature of the psychological phenomenon we try to understand; (b) different phenomena have different relations to each of the temporal dimensions; (c) the multidimensional nature of the TP is manifest; (d) specifically regarding this study, the "negative" dimensions of TP are the ones with most predictive power; being also negatively related with those constructs and (e) TP predictive capabilities are more accurate in determinate constructs than others (e.g., good regarding Satisfaction with Life and Psychological Well-Being, acceptable about Emotional Balance and poor concerning Interpersonal Relations).

\section{REFERENCES}

Boyd, J. N., \& Zimbardo, P. G. (1997). Constructing time after death: The transcendental future time perspective. Time and Society, 6(1), 35-54.

Boyd, J., Zimbardo, P. (2005). Time Perspective, Health and Risk Taking. In: Strathman A. \& Joireman J. (Eds). Understanding behavior in the context of time (pp 85-107). Mahwah, N.J.: LEA.

Diener, E., Emmons, R. A., Larsen, R. J., \& Griffin, S. (1985). The satisfaction with life scale. Journal of Personality Assessment, 49(1), 71-75.

Diniz, A. \& Almeida, L. (2005). Escala de Integração Social no Ensino Superior (EISES): Metodologia de Construção e Validação. Análise Psicológica, 4 (XXIII), 461-478.

Drake, L., Duncan, E., Sutherland, F., Abernethy, C., \& Henry, C. (2008). Time Perspective and Correlates of Wellbeing. Time \& Society, 17, 47-61.

JaneIro, I. N. (2006). A perspectiva temporal, as crenças atribucionais, a auto-estima e as atitudes de planeamento e de exploração da carreira - estudo sobre os determinantes da maturidade na carreira em estudantes dos 9. $\mathrm{e} 12 .^{\circ}$ anos. Dissertação de doutoramento (não publicada). Faculdade de Psicologia e de Ciências da Educação da Universidade de Lisboa.

LEwIN. K. (1951). Field theory in the social sciences: Selected theoretical papers. New York: Harper.

Neto, F. (1993). The Satisfaction with Life Scale: Psychometrics Properties in an Adolescent Sample. Journal of Youth and Adolescence, 22(2), 125-134.

Ortuño, V. \& Gamboa, V. (2008) Estudo Preliminar de Adaptação ao Português do Zimbardo Time Perspective Inventory - ZTPI, Actas da XIII Conferencia Internacional de Avaliação Psicológica: Formas e Contextos, Braga: Universidade do Minho.

Ortuño, V. E. \& Gamboa, V. M. (2009). Estrutura factorial do Zimbardo Time Perspective Inventory - ZTPI numa amostra de estudantes universitários portugueses. Avances en Psicología Latinoamericana, 27(1), 21-32. 
Ortuño, V. E., Paixão, M. P. \& Janeiro, I. (2011). Tempo e Universidade: A Evolução da Perspectiva Temporal ao Longo do Percurso Universitário. In Faria, L., Araújo, A., Morais, F., Sá, E., Pinto, J. \& Silva, A, Carreira, Criatividade e Empreendedorismo (pp 217-225). Braga: APDC Ediçôes. Ortuño, V. E., Paixão, M. P. \& Janeiro, I. N. (2013). Tempus Post Mortem? Adaptação Portuguesa da Transcendental-Future Time Perspective Scale - TFTPS. Revista Latinoamericana de Psicologia, 31(2), 376-388.

Zimbardo, P. G. \& Boyd, J. N. (1999). Putting time in perspective: A valid, reliable individual differences metric. Journal of Personality and Social Psychology, 77(6), 1271-1288. 